\title{
ADAPTABILITY AND STABILITY OF EARLY CARIOCA BEANS BY MIXED MODELS
}

\author{
ADAPTABILIDADE E ESTABILIDADE DE FEIJÃO CARIOCA PRECOCE VIA \\ MODELOS MISTOS
}

\section{Thalyson Vasconcelos LIMA ${ }^{1}$; Paulo Ricardo dos SANTOS ${ }^{2}$; Tâmara Rebecca Albuquerque de OLIVEIRA ${ }^{3}$; Maxwel Rodrigues NASCIMENTO ${ }^{3}$; Kleyton Danilo da Silva COSTA ${ }^{4}$; Antônio Félix da COSTA ${ }^{5}$; Katiane da Rosa Gomes da SILVA ${ }^{5}$; Thiago Lívio Pessoa OLIVEIRA ${ }^{6}$; Emmanuelle Rodrigues ARAÚJO ${ }^{\mathbf{5}}$; José Wilson da SILVA ${ }^{1}$}

1. Postgraduate Program in Agronomy (Plant Breeding), Rural Federal University of Pernambuco - UFRPE, Recife, Pernambuco, Brazil; 2. Center for Agrarian Sciences and Biodiversity, Federal University of Cariri - UFCA, Crato, Ceará, Brazil; 3. Postgraduate Program in Genetics and Plant Breeding, State University of the North Fluminense Darcy Ribeiro - UENF, Campos dos Goytacazes,

Rio de Janeiro, Brazil. maxwel.rn88@gmail.com; 4. Federal Institute of Alagoas, Piranhas - IFAL, Alagoas, Brazil; 5. Agronomic Institute of Pernambuco - IPA, Recife, Pernambuco, Brazil; 6. National Rice and Bean Research Center - CNPAF, Brazilian Agricultural Research Corporation - Embrapa Arroz e Feijão, Santo Antônio de Goiás, Goiás, Brazil.

\begin{abstract}
The genotype $x$ environment interaction represents one of the major selection challenges due to the difficulty in identifying effectively superior genotypes. The present study aimed at estimating genetic parameters and selecting genotypes of early Carioca beans by analyzing simultaneous attributes, including yield, adaptability, and stability. In the agricultural year of 2015 and 2016, three trials were conducted, using a randomized block design, with three repetitions each, in the Agreste and Sertao regions of Pernambuco State. The genetic parameters were estimated using the mixed model procedure, and the selection was based on the harmonic mean of the relative performance of genetic values (MHPRVG, abbreviation in Portuguese) method. The environments influenced the phenotypic expression of the bean genotypes during both years, setting a specific adaptation. The mean heritability of the genotypes regarding yield exhibited low magnitude values in the trials of $2015(5.78 \%)$ and $2016(13.77 \%)$, indicating costly conditions for the selection of the improved genotypes. Genotype CNFC 15856 was selected, considering the genetic gain predicted for yield, by the average and specific performance in the three environments, and by the simultaneous attributes of yield, adaptability, and stability. The MHPRVG method enables the optimized selection of genotypes considering yield, stability, and adaptability; therefore, it should be included in the recommended selective criteria for agronomically superior genotypes in commercial plantations.
\end{abstract}

KEYWORDS: Genotype x environment interaction. Phaseolus vulgaris L. Predicted genotypic values. REML/BLUP.

\section{INTRODUCTION}

Common bean (Phaseolus vulgaris L.) is one of the most significant and traditional crops in Brazil and is primarily cultivated by small family farmers. This crop has performed an important social role, as it provides work and income in rural areas.

As Brazil is the largest consumer worldwide and the third-largest producer, it yields three harvests throughout the year with a yield of 3.2 million tons. However, the Brazilian bean yield has not been large enough to meet the domestic market demand (CONAB, 2020). According to Vieira (2006), several biotic and abiotic problems affecting bean crops have been reported and should be the subject of breeding programs, with emphasis on grain yield. Thus, bean breeding programs play a leading role and take up the challenges of developing new cultivars for higher grain yields and reducing bean imports from abroad.

However, the research relating to the selection gain of this culture is hampered by the effect of each environment in which the lineages are tested, considering the genotypes $\mathrm{x}$ environment interaction. Such interaction comprises one of the most substantial challenges in plant breeding, both in the selection procedures and cultivar recommendations, since breeders seek stable and better-performing genotypes regarding a particular characteristic (RAMALHO et al., 2012).

Accordingly, selection methodologies that include yield stability and adaptability into a single statistic may be considered superior compared to 
those that use only yield as a selection criterion (VERARDI et al., 2009). Since beans are a widely cultivated crop for different regions in Brazil, analysis of adaptability and stability become necessary for a consistent recommendation of high yielding genotypes. Among many methods for explaining the genotype and environment interaction, the REML/BLUP (Best Linear Unbiased Prediction) stands out for its practicality to interpret results and the accuracy in selecting genotypes (SANTOS et al., 2017).

The estimates of genetic values via REML/BLUP enable the selection of genotypes to simultaneous considerations of yield, stability, and adaptability. The harmonic mean of the relative performance of genetically predicted values (MHPRVG, abbreviation in Portuguese) method constitutes an alternative proposed by Resende (2002). The mixed model for the genotype $x$ environment interaction considers genotypic effects to be random. Thus, it provides genotypic adaptability and stability, which allows the analysis of imbalanced data and non-orthogonal designs, with a heterogeneity of variances. Moreover, it enables considering correlated errors within environments, as well as adaptability and stability in the selection of individuals within genotypes; it provides breeding values already having discounted instability; and may be applied to any number of environments. It also generates results in the unit itself or the scale of the trait evaluated, which may be directly interpreted as breeding values that are not allowed by other methods. This model also allows additional inferences, such as the selection of specific genotypes for each environment; selection of stable genotypes (high predictability) in different environments and years; selection of genotypes (high adaptability) responsive (high adaptability) to the improvement of the environment; and simultaneous selection for yield, stability, and adaptability (CARVALHO et al., 2016; GONÇALVES et al., 2014; SANTOS et al., 2017; SANTOS et al., 2018; SANTOS et al., 2019; SOUZA et al., 2018).

The present work aimed at determining the efficiency of the simultaneous selection of bean precultivars of the early Carioca commercial group for yield, stability, and adaptability, using the mixed models (REML/BLUP) and the harmonic mean of the relative performance of the genetic values (MHPRVG).

\section{MATERIAL AND METHODS}

In the agricultural years of 2015 and 2016, different genotypes of early Carioca beans were evaluated (Table 1). The trials were carried out in five experimental stations of the Instituto Agronomico de Pernambuco - IPA (Pernambuco Agronomic Institute), distributed in five counties (Table 2), using a randomized block design with three repetitions each. Each experimental unit consisted of 4 lines of $4 \mathrm{~m}$, with a spacing of $50 \mathrm{x}$ $20 \mathrm{~cm}$, totaling a population of 100 thousand plants $\mathrm{ha}^{-1}$. Data collection was performed on the two central rows, while the border lines were disregarded. Before the implementation of the experiments, a chemical analysis of the soil that received the sowing fertilization $\left(200 \mathrm{~kg} \mathrm{ha}^{-1}\right.$ of chemical fertilizer 04-20-20) was done, according to Cavalcanti (2008). Soil preparation was conventionally carried out way, with plowing and two light harrowings.

Manual weeding was used for weed control. The methamidophos insecticide was applied weekly, at a dose of $0.5 \mathrm{~L} \mathrm{ha}^{-1}$, for the control of thrips and whiteflies from day 7 to day 50 after the emergence of plants, using a manual costal spray (Boiça Júnior et al., 2000). When necessary, additional irrigation was performed by a conventional sprinkler system.

Table 1. Early Carioca bean genotypes and their origin evaluated in the agricultural years of 2015 and 2016 in counties of Pernambuco.

\begin{tabular}{cccc}
\hline Early Carioca Bean 2015 & Origin & Early Carioca Bean 2016 & Origin \\
\hline CNFC 15630 & Embrapa & CNFC 15874 & Embrapa \\
CNFC 15873 & Embrapa & IAC Imperador & IAC \\
CNFC 15502 & Embrapa & CNFC 16066 & Embrapa \\
CNFC 15874 & Embrapa & CNFC 15708 & Embrapa \\
CNFC 15629 & Embrapa & CNFC 16729 & Embrapa \\
CNFC 15625 & Embrapa & CNFC 16242 & Embrapa \\
CNFC 15875 & Embrapa & IPR Andorinha & Iapar \\
CNFC 15626 & Embrapa & CNFC 16831 & Embrapa
\end{tabular}




$\begin{array}{cccc}\text { BRS Notável } & \text { Embrapa } & \text { TAA GOL } & \text { TAA } \\ \text { IPR Colibri } & \text { Iapar } & \text { CNFC 15723 } & \text { Embrapa } \\ \text { Carioca Precoce } & \text { Embrapa } & \text { CNFC 15856 } & \text { Embrapa } \\ - & - & \text { CNFC } 16820 & \text { Embrapa } \\ - & - & \text { CNFC } 16871 & \text { Embrapa } \\ - & - & \text { CNFC } 16846 & \text { Embrapa } \\ - & - & \text { BRS Notável } & \text { Embrapa } \\ - & - & \text { CNFC 16832 } & \text { Embrapa } \\ - & - & \text { CNFC 16188 } & \text { Embrapa }\end{array}$

Table 2. Characteristics of the counties of Pernambuco where early Carioca bean genotypes were evaluated.

Early Carioca Bean 2015

\begin{tabular}{lccccc}
\hline Environment & Topography & $\begin{array}{c}\text { Temperature } \\
\text { (Annual Mean) }\end{array}$ & $\begin{array}{c}\text { Precipitation } \\
\text { Index }\end{array}$ & Altitude & Soil Type \\
\hline Araripina & S. wavy & $25.3^{\circ} \mathrm{C}$ & $683.8 \mathrm{~mm}$ & $622 \mathrm{~m}$ & Plain soil \\
Arcoverde & Wavy & $25.4^{\circ} \mathrm{C}$ & $697.5 \mathrm{~mm}$ & $663 \mathrm{~m}$ & R. Neutrophic \\
Brejão & Wavy & $23.2^{\circ} \mathrm{C}$ & $1484.8 \mathrm{~mm}$ & $754 \mathrm{~m}$ & Y. Latosol \\
\hline \multicolumn{7}{c}{} & Early Carioca bean $\mathbf{2 0 1 6}$ & & \\
\hline Environment & Topography & Temperature & Precipitation & Altitude & Soil Type \\
\hline Arcoverde & (Annual Mean) & Index & & R. Neutrophic \\
Belém São Francisco & S. wavy & $25.0^{\circ} \mathrm{C}$ & $705.5 \mathrm{~mm}$ & $663 \mathrm{~m}$ & Plain soil \\
Caruaru & Wavy & $24.3^{\circ} \mathrm{C}$ & $506.5 \mathrm{~mm}$ & $305 \mathrm{~m}$ & Neossoil \\
\hline
\end{tabular}

$\mathrm{S}=$ Smooth-wavy; R. = Regolith Neossoil; Y.= Yellow (APAC, 2019).

Grain yields were obtained in all experiments. The adaptability and stability evaluation was performed using the REML/BLUP (restricted maximum likelihood/best linear unbiased prediction) methodology (Henderson, 1975), considering the following statistical model: $y=X r+$ $Z g+W i+e$, in which: $y$ represents fixed effect data vector (means of the site blocks), the genotypic effects of genotypes (random), effects of genotype $\mathrm{x}$ environment interaction (random), and errors or residues (random); and $X, Z$, and $W$ denote the incidence matrices for $r, g$, and $i$, respectively.

The equations of the mixed model, equivalent to the prediction of $r, g$, and $i$, comprised the following:

$$
\begin{aligned}
& {\left[\begin{array}{ccc}
X^{\prime} X & X^{\prime} Z & X^{\prime} W \\
Z^{\prime} X & Z^{\prime} Z+\lambda_{1} & Z^{\prime} W \\
W^{\prime} X & W^{\prime} Z & W^{\prime} W+\lambda_{2}
\end{array}\right]=\left[\begin{array}{l}
\hat{r} \\
\hat{g} \\
\hat{i}
\end{array}\right]=\left[\begin{array}{c}
X^{\prime} y \\
Z^{\prime} y \\
W^{\prime} y
\end{array}\right],} \\
& \text { in which: } \\
& \lambda_{I}=\frac{l-h_{g}^{2}-h_{i}^{2}}{h_{g}^{2}} ; \quad \lambda_{2}=\frac{l-h_{g}^{2}-h_{i}^{2}}{h_{i}^{2}} ;
\end{aligned}
$$

in which: $h_{g}^{2}=$ individual heritability in the broad sense at block level; $h_{i}^{2}=$ coefficients of determination of the effects of the genotype $\mathrm{x}$ environment interaction.

For the genetic evaluation to obtain the highest values of the harmonic mean of the genotypic values, the MHPRVG method was employed, as described by Resende (2002):

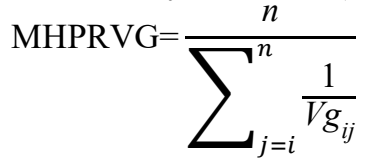

in which: $\mathrm{n}$ represents the number of sites where genotype $\mathrm{i}$ was evaluated; and $\mathrm{Vg}_{\mathrm{ij}}$ is the genotypic value of genotype $i$ at site $j$, expressed as the ratio of the mean of that site.

The mixed model used comprises the main genotypic effects and the genotype $\mathrm{x}$ environment interaction by means of $\mathrm{G}+\mathrm{GE}$ to obtain the multivariate BLUP. The BLUP of the G $\mathrm{x}$ E effects was used to eliminate failures of the genotype $\mathrm{x}$ environment interaction. Genotypes with the best 
performance were evaluated in three ways by the MHPRVG method: selection based on the predicted genetic value by means of the average behavior in all locations with no interaction; selection based on the predicted genetic value considering the behavior of the genotypes in each location with the effect of the average interaction; and simultaneous selection for yield, stability (MHVG), and adaptability (PRVG). Model 54 of the Selegen computer system (RESENDE, 2016) was used to evaluate lineages and cultivators in complete block designs, in several locations and one observation per plot. A joint analysis was conducted in the common bean group for each agricultural year 2015 and 2016 MHPRVG method.

\section{RESULTS AND DISCUSSION}

The experimental coefficient of variation was $31.82 \%$ for the experiments with early Carioca beans evaluated in 2015 and $21.25 \%$ for the genotypes analyzed in 2016 (Table 3). Although these values are regarded as of high magnitude due to grain yield, such estimates are expected since the characteristic is strongly influenced by local edaphoclimatic conditions (RAMALHO et al., 2012).

Table 3. Analysis of deviance and estimates of genetic parameters (individual REML) for grain in common bean genotypes of early carioca evaluated 90 days after emergence in the counties of Araripina, Arcoverde, Caruaru Belém do São Francisco, and Brejão, in the agricultural years of 2015 and 2016.

\begin{tabular}{|c|c|c|}
\hline Effect & $\begin{array}{l}\text { LRT Chi-Square }\left(\chi^{2}\right) \\
\text { Early Carioca } 2015\end{array}$ & $\begin{array}{l}\text { LRT Chi-Square }\left(\chi^{2}\right) \\
\text { Early Carioca } 2016\end{array}$ \\
\hline Genotypes & $6.9^{* *}$ & $8.2^{* *}$ \\
\hline Genotype $\mathrm{x}$ environment interaction & $298.38^{* *}$ & $378.68^{* *}$ \\
\hline Environment & $67.34^{* *}$ & $83.18^{* *}$ \\
\hline Complete Deviance Model & 4457.43 & 4530.19 \\
\hline Components of variance (Individual REML) & $\begin{array}{l}\text { Early Carioca Bean } 2015 \\
\left(\mathrm{~kg} \mathrm{ha}^{-1}\right)\end{array}$ & $\begin{array}{l}\text { Early Carioca Bean } 2016 \\
\left(\mathrm{~kg} \mathrm{ha}^{-1}\right)\end{array}$ \\
\hline Genotypic variance & 1425.09 & 6936.03 \\
\hline Variance of genotype $\mathrm{x}$ environment interaction & 18015.77 & 49090.49 \\
\hline Residual variance & 154871.75 & 243697.24 \\
\hline Individual phenotypic variance & 174312.61 & 299723.76 \\
\hline $\begin{array}{l}\text { Individual broad sense heritability free from } \\
\text { interaction }\end{array}$ & $0.01 \pm 0.03$ & $0.02 \pm 0.03$ \\
\hline Average heritability & 0.06 & 0.14 \\
\hline Selective accuracy & 0.24 & 0.37 \\
\hline Genotype $\mathrm{x}$ environment interaction $\mathrm{R}^{2}$ & 0.1 & 0.16 \\
\hline $\begin{array}{l}\text { Genotypic correlation of performance in different } \\
\text { environments }\end{array}$ & 0.07 & 0.12 \\
\hline Genotypic coefficient of variation (\%) & 5.37 & 2.04 \\
\hline Coefficient of experimental variation (\%) & 31.82 & 21.26 \\
\hline Overall mean & 1877.18 & 1851.36 \\
\hline
\end{tabular}

${ }^{+}$Deviance of adjusted model without the effects cited; distribution for 1 degree of freedom. LRT, likelihood; ${ }^{* *}$ significant by chi-square, test at $1 \%(6.63)$ probability.

Genotypes, environments, and the genotype $\mathrm{x}$ environment interaction for the Carioca bean evaluated in 2015 and 2016 were significant at $1 \%$ of probability, by the Chi-square test, respectively (Table 3). These results indicate that the genotypes of the early Carioca bean group differed genetically for grain yield potential and presented a different response to the environments where they were evaluated. This could be performed by the analyses of adaptability and stability, considering that edaphoclimatic factors have the greatest effect on the adaptability and stability of genotypes (TORRES et al., 2015; SANTOS et al., 2018).

On the other hand, the values obtained regarding the coefficient of genetic variation varied from 2.04 in 2016 to 5.36 in 2015, indicating that the low fraction of genetic variances was taken from the total phenotypic variation. The coefficient of 
Adaptability and stability...

genetic variation quantifies the magnitude of the genetic variation available for selection; therefore, high values are desirable. It observed only in the experiments with the genotypes evaluated in 2015 .

According to Resende; Duarte (2007), the simultaneous evaluation of the coefficients of genetic and experimental variation is shown in the selective accuracy parameter $\left(\hat{r}_{\mathrm{gg}}\right)$. The $\hat{\mathrm{r}}_{\mathrm{gg}}$ obtained for the genotypes evaluated in 2016 presented a value of $37.11 \%$, revealing a reasonable experimental quality, therefore, efficiency in the selection of superior genotypes considering the yield trait in beans. However, those evaluated in 2015 showed low values of $\hat{r}_{\mathrm{gg}}(24.05 \%)$, indicating an inferior selective efficiency of agronomically superior genotypes.

The values for the average heritability of the genotypes $\left(\mathrm{h}_{\mathrm{m}}^{2}\right)$ varied from 0.06 to 0.14 , denoting that, although expensive, it is possible to obtain gains with the selection of early Carioca bean genotypes, based on the predicted genotypic values. Individual heritability, in the broad sense, free from interaction, considers total genetic dispersion and allows exploring the whole genetic variance among bean genotypes (TORRES et al., 2015).

Regarding the genotypes evaluated in 2015 and 2016, the variances of the genotypic effects ranged between 1425.09 and 6936.03. These magnitudes were lower than the variances of the effects concerning the $G \times E$ interaction and constituted $0.82 \%$ and $2.32 \%$ of the total phenotypic variability, respectively, represented by the heritability of individual plots $(0.027$ and 0.0348 , respectively). When estimating genetic parameters
LIMA, T. V. et al.

via REML/BLUP in different cultures, Torres et al. (2015) and Carvalho et al. (2016) observed similar magnitude results.

High magnitude estimates of variance of the G x E interaction were obtained for the genotypes evaluated in 2015 (18015.77) and 2016 (49090.49), suggesting that the interaction significantly influences the phenotypic value. In this context, genotypes with higher yield in an environment tend to exhibit distinct performances in several environments, in addition to unpredictability and low adaptation to environmental variations. Consequently, low values of genotypic correlation were obtained in the different environments, which caused changes in the order of the genotypes selected (SOUZA et al., 2018; SANTOS et al., 2019).

Thus, the results presented by the genetic parameters denoted a high interaction between $\mathrm{G} x$ $\mathrm{E}$, indicating a complex interaction between genotypes and environments, favoring the selection of genotypes of more specific adaptation.

Despite the high residual variance valuesamong plots, significant genetic progress was achieved (TORRES et al., 2015; CARVALHO et al., 2016). Therefore, the selection of the best genotypes was carried out by three different approaches.

In the selection of the six best early Carioca bean genotypes for trials in 2015, the improved genotype CNFC 15630 showed higher grain productivity $(u+g+g e m=1923.41)$, considering the average performance in all environments (Table 4).

Table 4. Estimates of predicted genetic gain for grain productivity $\left(\mathrm{kg} \cdot \mathrm{ha}^{-1}\right)$ in bean cultivars considering the average performance in the six environments in Pernambuco state, in Brazil.

\begin{tabular}{ccccccc}
\hline Order & Genotype & $\boldsymbol{g}^{(\mathbf{1})}$ & $\boldsymbol{u}+\boldsymbol{g}$ & Gain & New Mean & $\boldsymbol{u + g}+\boldsymbol{g e m}$ \\
\hline \multicolumn{6}{c}{ Early Carioca 2015 } \\
\hline 1 & CNFC 15630 & 13.82 & 1865.18 & 13.82 & 1865.18 & 1923.41 \\
2 & CNFC 15875 & 9.43 & 1860.79 & 11.62 & 1862.98 & 1900.52 \\
3 & Carioca Precoce & 4.60 & 1855.96 & 9.28 & 1860.64 & 1875.36 \\
4 & CNFC 15625 & 4.47 & 1855.83 & 8.08 & 1859.44 & 1874.69 \\
5 & CNFC 15626 & 4.36 & 1855.72 & 7.34 & 1858.70 & 1874.10 \\
6 & IPR Colibri & 0.00 & 1850.59 & 5.99 & 1857.35 & 1847.34 \\
\hline \multicolumn{7}{c}{ Early Carioca 2016 } \\
\hline 1 & CNFC 15856 & 49.50 & 1600.68 & 49.50 & 1600.68 & 1717.46 \\
2 & CNFC 16846 & 49.08 & 1600.26 & 49.29 & 1600.47 & 1716.04 \\
3 & CNFC 16242 & 28.42 & 1579.59 & 42.33 & 1593.51 & 1646.64 \\
4 & BRS Notável & 23.64 & 1574.81 & 37.66 & 1588.83 & 1630.57 \\
5 & CNFC 15723 & 22.79 & 1573.97 & 34.69 & 1585.86 & 1627.75 \\
6 & CNFC 16831 & 18.43 & 1569.61 & 31.98 & 1583.15 & 1613.09 \\
\hline
\end{tabular}

\footnotetext{
${ }^{(1)}$ Estimates: g, genotypic effect; $\mathrm{u}+\mathrm{g}$, predicted genotypic value; and $\mathrm{u}+\mathrm{g}+\mathrm{gem}$, mean genotypic value in the environments.
} 
Adaptability and stability...

The predicted genetic gain of this genotype was superior to the commercial genotypes of early Carioca beans, IPR Colibri, and BRS Notável. Due to the conservative nature of the method, which penalizes the predicted genotypic values, the same behavior of the genetic means (predicted genotypic value, $u+g$ ) of the characteristic is expected when the chosen genotypes are submitted to different environments. Therefore, the magnitudes of the genetic gain values may be considered for bean recommendations for the selection of genetic material with average performance in the municipalities of Araripina, Arcoverde, and Brejão.

Regarding the selection of the six best genotypes in the trials conducted during the agricultural year of 2016, the genotypes CNFC 15856, CNFC 16846, CNFC 16242, BRS Notável, CNFC 15723, and CNFC 16831 demonstrated the most significant levels of grain yield based on the average performance in all the environments, with
LIMA, T. V. et al.

genotypic values free from the interaction. The predicted genetic gain of the improved genotypes CNFC 15856, CNFC 16846, and CNFC 16242 were superior to that of the control BRS Notável.

The recommendation of the most stable and best-adapted genotypes to the different environments under analysis becomes inherent to the capitalization of the interaction. Among the methods evaluated, this was the one that least penalizes the predicted genotypic values since it capitalizes on the effects of the genotype $\mathrm{x}$ environment interaction of each environment (SANTOS et al., 2019; SILVA et al., 2013).

In the agricultural year of 2015, the four best genotypes (CNFC 15630, CNFC 15875, CNFC 15625 Carioca Precoce, and IPR Colibri) selected by the genetic mean free from interaction in the mean of the three environments remained superior and in the same order in Araripina and Arcoverde (Table 5).

Table 5. Estimate of predicted genetic gain for grain productivity $\left(\mathrm{kg} \cdot \mathrm{ha}^{-1}\right)$ in bean cultivars in six environments in Pernambuco State, Brazil.

\begin{tabular}{|c|c|c|c|c|c|c|}
\hline \multirow{2}{*}{ Environment } & Order & Genotypes & $g+g e$ & $u+g+g e$ & Gain & New Mean \\
\hline & \multicolumn{6}{|c|}{ Early Carioca Bean 2015} \\
\hline \multirow{6}{*}{ Araripina } & 1 & Carioca Precoce & 85.10 & 1753.37 & 85.13 & 1753.10 \\
\hline & 2 & CNFC 15630 & 58.96 & 1700.55 & 60.37 & 1701.96 \\
\hline & 3 & CNFC 15875 & 44.73 & 1686.31 & 55.16 & 1696.74 \\
\hline & 4 & CNFC 15625 & 30.06 & 1671.64 & 48.88 & 1690.47 \\
\hline & 5 & CNFC 15874 & 27.58 & 1669.16 & 44.62 & 1686.21 \\
\hline & 6 & BRS Notável & 15.97 & 1657.56 & 39.85 & 1681.43 \\
\hline \multirow{6}{*}{ Arcoverde } & 1 & CNFC 15625 & 103.76 & 1873.51 & 103.76 & 1873.51 \\
\hline & 2 & CNFC 15825 & 59.47 & 1813.22 & 81.62 & 1857.37 \\
\hline & 3 & CNFC 15630 & 52.39 & 1806.14 & 71.87 & 1852.62 \\
\hline & 4 & CNFC 15873 & 52.18 & 1805.93 & 66.95 & 1847.70 \\
\hline & 5 & Carioca Precoce & 34.34 & 1802.09 & 61.23 & 1840.98 \\
\hline & 6 & IPR Colibri & 2.23 & 1755.98 & 45.56 & 1835.31 \\
\hline \multirow{6}{*}{ Brejão } & 1 & CNFC 15875 & 127.6 & 2310.35 & 127.60 & 2310.35 \\
\hline & 2 & CNFC 15630 & 101.75 & 2289.50 & 114.68 & 2302.43 \\
\hline & 3 & IPR Colibri & 48.83 & 2207.58 & 92.73 & 2292.48 \\
\hline & 4 & Carioca Precoce & 19.80 & 2178.55 & 74.49 & 2279.24 \\
\hline & 5 & CNFC 15874 & 15.59 & 2174.34 & 62.71 & 2263.46 \\
\hline & 6 & CNFC 15625 & 6.39 & 2154.36 & 51.53 & 2251.28 \\
\hline \multicolumn{7}{|c|}{ Early Carioca Bean 2016} \\
\hline \multirow{6}{*}{ Caruaru } & 1 & BRS Notável & 152.40 & 1036.08 & 152.40 & 1036.08 \\
\hline & 2 & CNFC 15874 & 97.88 & 981.55 & 125.14 & 1008.82 \\
\hline & 3 & IAC Imperador & 58.41 & 942.09 & 102.90 & 986.57 \\
\hline & 4 & CNFC 15856 & 56.15 & 939.83 & 91.21 & 974.89 \\
\hline & 5 & CNFC 15723 & 39.50 & 923.18 & 80.87 & 964.54 \\
\hline & 6 & CNFC 16188 & 31.17 & 914.84 & 72.58 & 956.26 \\
\hline \multirow{5}{*}{ Arcoverde } & 1 & CNFC 15856 & 175.43 & 1937.44 & 175.43 & 1937.44 \\
\hline & 2 & CNFC 15723 & 150.94 & 1912.95 & 163.18 & 1925.19 \\
\hline & 3 & CNFC 16846 & 117.10 & 1879.11 & 147.82 & 1909.83 \\
\hline & 4 & CNFC 16871 & 68.53 & 1830.54 & 128.00 & 1890.01 \\
\hline & 5 & CNFC 16066 & 34.41 & 1796.42 & 109.28 & 1871.29 \\
\hline
\end{tabular}


Adaptability and stability...

LIMA, T. V. et al.

\begin{tabular}{ccccccc} 
& 6 & CNFC 16820 & 19.82 & 1781.83 & 94.37 & 1856.38 \\
\hline & 1 & CNFC 16846 & 386.73 & 2394.57 & 386.73 & 2394.57 \\
Belém de São & 2 & CNFC 16831 & 289.78 & 2297.63 & 338.26 & 2346.10 \\
Francisco & 3 & CNFC 16242 & 272.47 & 2280.31 & 316.33 & 2324.17 \\
& 4 & CNFC 15856 & 267.09 & 2274.93 & 304.02 & 2311.86 \\
& 5 & CNFC 16729 & 159.32 & 2167.16 & 275.08 & 2282.92 \\
& 6 & BRS Notável & 114.74 & 2122.58 & 248.35 & 2256.20 \\
\hline
\end{tabular}

${ }^{(1)}$ Estimates: $g+g e$, genotypic effect per each environment; and $u+g+g e$, predicted genotypic value with capitalization of the interaction with the environments.

In contrast to what was observed in the selection by the genetic mean considering the average of the environments, Arcoverde and Brejão coincided in the selection of the genotypes CNFC 15630, CNFC 15875, CNFC 15625, Carioca Precoce, IPR Colibri, and CNFC 15874. It can be inferred that the genotypes selected in Araripina, Arcoverde, and Brejão interact but in a simple way with the environment, as proven by the inconstancy in which they are presented in order of classification in the three environments. This result was expected when considering the high values of the variance of the G x E interaction (18015.77) and the low level of the genotypic correlation of performance in the different environments (0.07).

Similarly, considering the genotypes evaluated in 2016, each environment obtained a distinct pattern in the order of the genotypes selected for high grain yield, which implicates the recommendation of genotypes to specific environments. The genotype CNFC 15856 was the only one that was among the six best genotypes, in the municipalities of Caruaru, Arcoverde, and Belém de São Francisco, exhibiting predicted genotypic values with the capitalization of the interaction with the environments $(u+g+g e)$ of $939.83 \mathrm{~kg} \mathrm{ha}^{-1}, 1937.44 \mathrm{~kg} \mathrm{ha}^{-1}$, and $2274.93 \mathrm{~kg} \mathrm{ha}^{-}$ ${ }^{1}$, respectively.

In selecting the six best early Carioca bean genotypes evaluated in the agricultural years of
2015 and 2016, regarding all the environments, the predicted genetic gain was much lower than the selection per environment. Such a result can be attributed to the best capitalization of the effects of the genotype $\mathrm{x}$ environment interaction on the selection strategy per environment when compared to the selection of all environments based on the genetic value (TORRES et al., 2015; CARVALHO et al., 2016).

The estimation of adaptability and stability completes the study of the $\mathrm{G} \times \mathrm{E}$ interaction, that is, it determines the level of response of the genotypes to the environmental stimulus and the yield predictability in face of environmental variations (CARVALHO et al., 2016).

Regarding the 2015 trials, considering the genotypic selection in all the environments, the six best genotypes were also selected based on the best agronomic response. By way of the MHPRVG method, for grain yield, the genotypes CNFC 15630, CNFC 15875, CNFC 15625, Carioca Precoce, IPR Colibri, and CNFC 15625 were selected (Table 6), even undertaking the control BRS Notável. The stability and adaptability results for these genotypes, however, are not consistent with the results of the selection conducted for each environment. Thus, in this case, it can be inferred that the selection of genotypes considering high yield, predictability, and adaptation was specific for the municipalities of Araripina, Arcoverde, and Brejão.

Table 6. Stability and adaptability (MHPRVG and MHPRVG * MG) of genetic genotypic values in bean cultivars for grain yield in beans, in Pernambuco state, Brazil.

\begin{tabular}{cccc}
\hline \multirow{2}{*}{ Order } & \multicolumn{3}{c}{ Early Carioca Bean 2015 } \\
\cline { 2 - 4 } & Genotype & MHPRVG & MHPRVG*MG \\
\hline 1 & CNFC15630 & 1.04 & 1958.02 \\
2 & Carioca Precoce & 1.03 & 1936.94 \\
3 & CNFC 15875 & 1.02 & 1894.03 \\
4 & CNFC 15625 & $1, .01$ & 1878.4 \\
5 & IPR Colibri & 1.01 & 1872.37 \\
6 & CNFC 15625 & 1.01 & 1872.12 \\
7 & CNFC 15874 & 1.00 & 1845.51
\end{tabular}




\begin{tabular}{cccc}
8 & CNFC 15502 & 0.99 & 1835.83 \\
9 & BRS Notável & 0.98 & 1818.77 \\
10 & CNFC15629 & 0.97 & 1794.08 \\
11 & CNFC15502 & 0.95 & 1765.87 \\
\hline \multirow{2}{*}{ Order } & & Early Carioca Bean 2016 & \\
\cline { 2 - 4 } & Genotype & MHPRVG & MHPRVG MG \\
\hline 1 & CNFC 15856 & 1.1 & 1703.15 \\
2 & CNFC 16846 & 1.08 & 1669.77 \\
3 & BRS Notável & 1.07 & 1652.77 \\
4 & CNFC 15723 & 1.05 & 1627.59 \\
5 & CNFC 16242 & 1.05 & 1625.87 \\
6 & IAC Imperador & 1.02 & 1579.03 \\
7 & CNFC 16871 & 1.02 & 1577.07 \\
8 & CNFC16729 & 1.01 & 1569.38 \\
9 & CNFC16831 & 1.01 & 1527.2 \\
10 & CNFC15874 & 0.98 & 1504.48 \\
11 & CNFC16820 & 0.97 & 1480.07 \\
12 & CNFC15708 & 0.95 & 1466.05 \\
13 & IPR Andorinha & 0.95 & 1465.7 \\
14 & CNFC16188 & 0.94 & 1463.93 \\
15 & CNFC 16832 & 0.94 & 1452.63 \\
16 & CNFC 16066 & 0.94 & 1341.43 \\
17 & TAA GOL & 0.86 & 159 \\
\hline
\end{tabular}

${ }^{(1)}$ MHPRVG, harmonic mean of relative performance of predicted genetic values; and MHPRVG * MG refers to MHPRVG multiplied by the overall mean in all environments.

As previously stated, the genotypes evaluated in the 2016 trials that appear classified in all the environments as the most productive ones are strongly influenced by the environment, consequently, they present high values of $\mathrm{G} \times \mathrm{E}$ interaction. As it happened regarding the selection considering all environments, five genotypes (CNFC 15856, CNFC 16846, BRS Notável, CNFC 15723, and CNFC 16242) displayed better agronomic performance with the use of the MHPRVG method for grain yield, being superior to the controls IAC Imperador and IPR Andorinha.

The results concerning grain yield, adaptability, and stability for the genotypes do not agree with those of the selection for Caruaru, Arcoverde, and Belém de São Francisco, which previously indicated the influence of each environment so the genotypes could present good performance. The genotype CNFC 15856 was present in the selection, considering the predicted genetic gain for yield by the average performance in the environments, for the three specific environments, and the simultaneous yield attributes, adaptability, and stability by the MHPRVG ${ }^{*} \mathrm{MG}$ $\left(1703.15 \mathrm{~kg} \mathrm{ha}^{-1}\right)$.

This finding implies that the simultaneous selection criterion based on adaptability, stability, and yield is effective in selecting the best genotypes according to their genotypic value, with the penalization of unstable genetic material and capitalization of the adaptability of the most stable ones (ROSADO et al., 2012; SANTOS et al., 2017; SANTOS et al., 2019).

\section{CONCLUSION}

The selection for grain yield constitutes an expensive condition in early Carioca bean genotypes, and it is recommended for specific environments.

The genotypes CNFC 15630 and CNFC 15856 were selected in 2015 and 2016, respectively, considering the predicted genetic gain for yield by the mean and specific performance in the three environments and the simultaneous yield, 
Adaptability and stability...

LIMA, T. V. et al.

adaptability, and stability attributes using MHPRVG

The MHPRVG method enables the optimized selection of genotypes for yield, stability,

and adaptability; therefore, it should be included in the recommended selective criteria for agronomically superior genotypes for commercial plantations.

RESUMO: A interação genótipos $\mathrm{x}$ ambientes representa um dos maiores desafios da seleção por dificultar a identificação de genótipos efetivamente superiores. O objetivo desta pesquisa foi estimar os parâmetros genéticos e, pelos atributos simultâneos de produtividade, adaptabilidade e estabilidade, selecionar genótipos de feijão carioca precoce. No ano agrícola de 2015 e 2016, foram conduzidos três ensaios sob o delineamento de blocos casualizados com três repetições no Agreste e Sertão de Pernambuco. Os parâmetros genéticos foram estimados pelo procedimento de modelos mistos, e a seleção baseou-se no método da média harmônica do desempenho relativo dos valores genéticos. Os ambientes influenciaram na expressão fenotípica dos genótipos de feijão nos dois anos, configurando adaptação específica. A herdabilidade média dos genótipos para produtividade apresentou valores de baixa magnitude nos ensaios de 2015 (5,78\%) e $2016(13,77 \%)$, indicando condições dispendiosas para seleção dos genótipos melhorados. O genótipo CNFC 15856 foi selecionado considerando o ganho genético predito para produtividade pelo desempenho médio e específico nos três ambientes e pelos atributos simultâneos de produtividade, adaptabilidade e estabilidade. O método MHPRVG proporciona seleção otimizada de genótipos quanto à produtividade, à estabilidade e à adaptabilidade e, portanto, deve fazer parte dos critérios seletivos de recomendação de genótipos agronomicamente superiores para plantios comerciais.

PALAVRAS- CHAVE: Interação genótipos $\mathrm{x}$ ambientes. Phaseolus vulgaris L. REML/BLUP. Valores genotípicos preditos.

\section{REFERENCES}

Agência Pernambucana de Águas e Clima - APAC. Boletim do clima: Síntese climática. Recife: APAC, 2018. 32 p. Available from: http://www.apac.pe.gov.br/. Accessed in: January 032019.

BOIÇA JÚNIOR, A. L.; MUÇOUÇAH, M. J.; SANTOS, T. M.; BAUMGARTNER, J. G. Efeito de cultivares de feijoeiro, adubação e inseticidas sobre Empoasca kraemeri Ross \& Moore, 1957 e Bemisia tabaci

(Gennadius, 1889). Acta Scientiarum, Maringá, v. 22, n. 4, p. 955-961, 2000.

http://dx.doi.org/10.4025/actasciagron.v22i0.2855.

CARVALHO, L. P.; FARIAS, F. J. C.; MORELLO, C. L.; TEODORO, P. E. Uso da metodologia REML/BLUP para seleção de genótipos de algodoeiro com maior adaptabilidade e estabilidade produtiva.

Bragantia. Campinas, v. 75, n. 3, p. 314-321, 2016. http://dx.doi.org/10.1590/1678-4499.275.

CAVALCANTI, F. J. A. Recomendações de adubação para o Estado de Pernambuco: segunda aproximação. Recife: Instituto Agronômico de Pernambuco, 2008, 212 p.

Companhia Nacional de Abastecimento - CONAB. Acompanhamento da safra brasileira de grãos, v.8, n.1. Brasília, 2020, 77 p.

GONÇALVES, G. M.; VIANA, A. P.; AMARAL JUNIOR, A. T.; RESENDE, M. D. V. Breeding new sugarcane clones by mixed models under genotype by environmental interaction. Scientia Agricola, Piracicaba, v. 71, n. 1, p. 66-71, 2014. https://doi.org/10.1590/S0103-90162014000100009.

HENDERSON, C. R. Best linear estimation and prediction under a selection model. Biometrics, Washington, v. 31, n. 2, p. 423-447, 1975. https://doi.org/10.2307/2529430.

RAMALHO, A. P. R.; ABREU. A. F. B.; SANTOS, J. B.; NUNES, J. A. R. Aplicações de genética quantitativa no melhoramento de plantas autógamas. Lavras: Editora UFLA, 2012, 522 p. 
RESENDE, M. D. V. Genética biométrica e estatística no melhoramento de plantas perenes. Brasília: Embrapa Informação Tecnológica, 2002. 975 p.

RESENDE, M. D. V. Software Selegen-REML/BLUP: a useful tool for plant breeding. Crop Breeding and Applied Biotechnology, Viçosa, v. 16, n. 4, p. 330-339, 2016. https://doi.org/10.1590/198470332016v16n4a49.

RESENDE, M. D. V.; DUARTE, J.B. Precisão e controle de qualidade em experimentos de avaliação de cultivares. Pesquisa Agropecuária Tropical, Goiânia, v. 37, n. 3, p. 182-194, 2007.

https://www.revistas.ufg.br/index.php/pat.

ROSADO, A. M.; ROSADO, T. B.; ALVES, A. A.; LAVIOLA, B. G.; BHERING, L. L. Seleção simultânea de clones de eucalipto de acordo com produtividade, estabilidade e adaptabilidade. Pesquisa Agropecuária Brasileira, Brasília, v. 47, n. 7, p. 964-971, 2012. https://doi.org/10.1590/S0100-204X2012000700013.

SANTOS, A. D.; AMARAL JÚNIOR, A. T. D.; KUROSAWA, R. D. N. F.; GERHARDT, I. F. S.; FRITSCHE NETO, R. GGE Biplot projection in discriminating the efficiency of popcorn lines to use nitrogen. Ciência e Agrotecnologia, Lavras, v. 41, n. 1, p. 22-31, 2017. https://doi.org/10.1590/1413-70542017411030816.

SANTOS, P. R.; COSTA, K. D. S.; NASCIMENTO, M. R.; LIMA, T. V.; SOUZA, Y. P.; COSTA, A. F.; SILVA, J. W. Simultaneous selection for yield, stability, and adaptability of carioca and black beans. Pesquisa Agropecuária Brasileira, v. 53, n. 6, p. 736-745. 2018. https://doi.org/10.1590/s0100-204x2018000600010.

SANTOS, P. R.; OLIVEIRA, T. R. A.; SKEEN, P.; NASCIMENTO, M. R.; COSTA, K. D. S.; ARAÚJO, E. R.; PEREIRA, H. S.; COSTA, A. F. GGE Biplot and REML/BLUP based-analysis of yield stability and adaptability for common beans in multi-environment trials. Revista Brasileira de Ciências Agrárias, Recife, v. 14, n. 2, p. 1-8, 2019. http://dx.doi.org/10.5039/agraria.v14i2a5657.

SILVA, G. A. P.; CHIORATO, A. F.; GONÇALVES, J. G. R.; PERINA, E. F.; CARBONELL, A. M. Análise da adaptabilidade e estabilidade de produção em ensaios regionais de feijoeiro para o Estado de São Paulo.

Revista Ceres, Viçosa, v. 60, n. 1, p. 59-65, 2013. https://doi.org/10.1590/S0034-737X2013000100009.

SOUZA, Y. P.; SANTOS, P. R.; NASCIMENTO, M. R.; COSTA, K. D. S.; LIMA, T. V.; OLIVEIRA, T. R. A; COSTA, A. F.; PEREIRA, H. S.; SILVA, J. W. Assessing the genotypic performance of carioca beans through mixed models. Ciência Rural, Santa Maria, v. 48, n. 7, p. 1-7, 2018. https://doi.org/10.1590/0103$\underline{8478 \mathrm{cr} 20170761 .}$.

TORRES, F. E.; TEODORO, P. E.; SAGRILO, E.; CECCON, G.; CORREA, A. M. Interação genótipo × ambiente em genótipos de feijão caupi semi prostrado via modelos mistos. Bragantia, Campinas, v. 74, n. 3, p. 255-260, 2015. http://dx.doi.org/10.1590/1678-4499.0099.

VERARDI, C. K.; RESENDE, M. D. V.; COSTA, R. B.; GONÇALVES, P. S. Adaptabilidade e estabilidade da produção de borracha e seleção em progênies de seringueira. Pesquisa Agropecuária Brasileira, Brasília, v. 44, n. 10, p. 1277-1282, 2009. https://doi.org/10.1590/S0100-204X2009001000010.

VIEIRA, C.; PAULA JÚNIOR, T. Z.; BORÉM A. Feijão 2ª edição. Viçosa: Editora UFV, 2006. 600 p. 